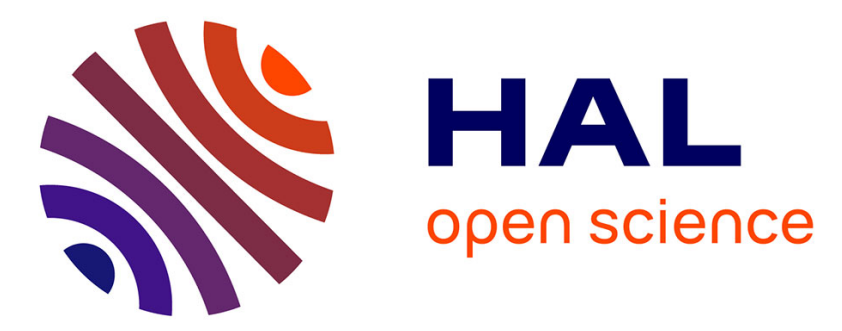

\title{
Decision support tools: Review of risk models in drinking water network asset management
}

\author{
A. Large, Yves Le Gat, S.M. Elachachi, Eddy Renaud, D. Breysse
}

\section{To cite this version:}

A. Large, Yves Le Gat, S.M. Elachachi, Eddy Renaud, D. Breysse. Decision support tools: Review of risk models in drinking water network asset management. 2nd International Conference on Vulnerability and Risk Analysis and Management (ICVRAM) and 6th International Symposium on Uncertainty Modelling and Analysis (ISUMA), Jul 2014, Liverpool, United Kingdom. 11 p. hal-01064036

\section{HAL Id: hal-01064036 https://hal.science/hal-01064036}

Submitted on 15 Sep 2014

HAL is a multi-disciplinary open access archive for the deposit and dissemination of scientific research documents, whether they are published or not. The documents may come from teaching and research institutions in France or abroad, or from public or private research centers.
L'archive ouverte pluridisciplinaire HAL, est destinée au dépôt et à la diffusion de documents scientifiques de niveau recherche, publiés ou non, émanant des établissements d'enseignement et de recherche français ou étrangers, des laboratoires publics ou privés. 


\title{
Decision support tools: Review of risk models in drinking water network asset management
}

\author{
A. Large ${ }^{1}$, Y. Le Gat ${ }^{1}$, S. M. Elachachi ${ }^{2}$, E. Renaud ${ }^{1}$ and D. Breysse ${ }^{2}$ \\ ${ }^{1}$ French National Research Institute of Science and Technology for Environment \\ and Agriculture, Water Networks Purification and Quality Unit, Centre of Bor- \\ deaux, 50 avenue de Verdun, 33612 Cestas, France; FAX 0(033)5 578908 01; \\ email: aurore.large@irstea.fr \\ ${ }^{2}$ University of Bordeaux, I2M, CNRS UMR 5295, Department of Environmental Civil \\ Engineering, 351 cours de la Liberation, 33405 TALENCE Cedex, France; FAX 0(0 \\ 33)5 400035 95; email: sm.elachachi@i2m.u-bordeaux1.fr
}

\begin{abstract}
An objective of infrastructure asset management of drinking water network is to minimize risks (service outage, or disruption of vehicular traffic...). However there are several methods to assess their frequency. This paper first discusses the different models used in predicting the structural deterioration, because it is a compulsory preliminary step to calculate risk. Risk models for service outage are then discussed.
\end{abstract}

\section{INTRODUCTION}

Most developed countries in the world have opted to transport drinking water to households via long networks of pipes, which are expensive to install and maintain. The total length of water pipes installed in France is approximately 900,000 km, compared with around 300,000 km in England and Wales. Underground pipe networks represent more than $80 \%$ of the total asset value for water distribution systems, and their management is therefore an important issue for water utilities (Renaud et al., 2012).

The overall objective of a water distribution system is to supply each consumer with enough good-quality water. The safety of the water network should be considered, and the overall costs should be acceptable. Regarding these objectives : i) enough water means fulfilling pressure and water demands. ii) water quality must comply with the established drinking water regulations and standards. iii) safety should be considered by means of reliability analysis and risk analysis. Thus, in practice water asset management is a complex multicriteria problem since managers must prevent or minimize damage: service outages, disruption of surface traffic (caused by maintenance works or water main bursts), flooding, interruption of business activities...

In order to help managers to deal with safety issues, a number of software applications have been developed during the last twenty years, usinge integrated 
models for risk evaluation(i.e. the level of potential damage due to some unexpected events). Nevertheless the models in these software do not assess the same risks and not in the same way.

Decision support tools for the management of drinking water pipes are often composed of several interrelated models (see figure 1). In the following, we will consider four families of models :

- M1 are models to predict the degradation of the basic functions of the pipes. For example, in estimating the future failure rate due to pipe collapse, or the number of pipes with ferruginous red water.

- M2 are risk models, i.e. they forecast the potential damage when vulnerable elements (water users, vehicles, goods, etc. ) are affected by hazard (break, leakage, red water ...).

- M3 are financial and economic models, they can monetize damage costs, repair costs, replacement costs, but also the benefits (which are often avoided damage or user satisfaction). These costs and benefits can be calculated from the point of view of the manager but also from the point of view of the whole society.

- M4 are decision models. They allow to take into account the priorities and decisions.

It is important to note that, at short term scale, the output of M1 are usually M2 inputs. Similarly, the outputs of M2 are M3 inputs, and M3 outputs are part of M4 inputs (see Figure 1). We will focus in the following on M2 (risk) models.

\section{PIPE FAILURE MECHANISMS}

Pipe condition is the cumulative effect of many factors acting on the pipe (Liu et al., 2012). Al-Barqawi and Zayed (2006) classified these factors into three categories: physical, environmental, and operational, as depicted in Figure 2. (Ana and Bauwens, 2010) explain that the occurrence and propagation of defects and the rate of structural deterioration are affected by these factors. The availability of accurate and sufficient amount of data on these factors plays a fundamental role in the development of many pipe deterioration and risk models.

\section{RISKS INDUCED BY PIPE FAILURES}

The word "risk" (R) has a broad meaning (Taillandier, F., 2009). In the field of infrastructure asset management, it refers to the possible occurrence of an event, which may be intentional or unintentional, and can lead to the loss of an object, or any other kind of damage. According to French regulations on hazardous industrial installations (Circulaire IC, 2005), this definition involves three physical components: i) hazard, ii) vulnerable element, and iii) damage. 


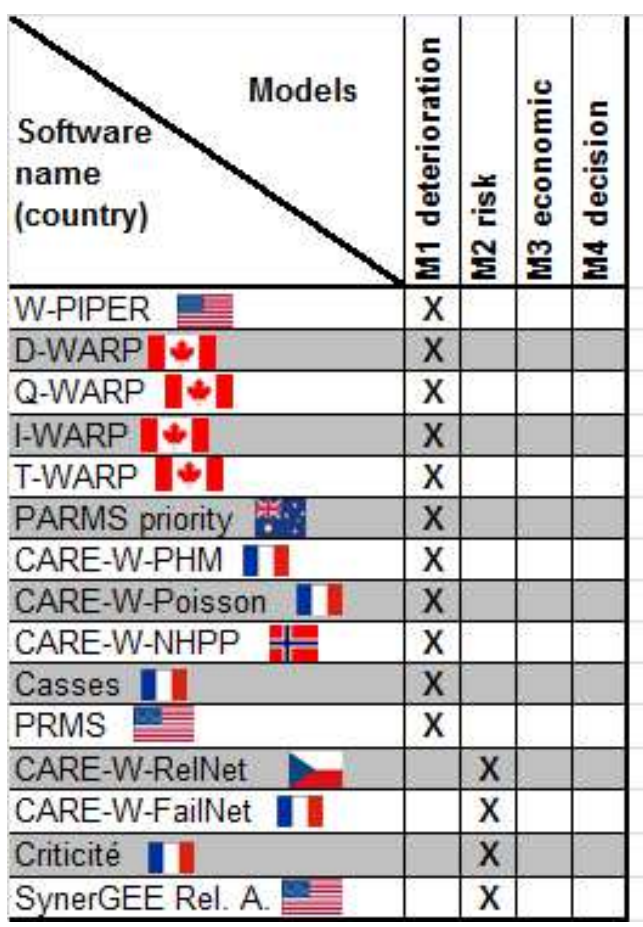

\begin{tabular}{l|l|l|l|l|} 
Software \\
name \\
(country)
\end{tabular}

Figure 1. Four different models in software for drinking water asset management

i) Hazard $(\mathrm{H})$ is an intrinsic property of a substance (lead...), a technical system (pipe failure...), or an organism (bacteria...) susceptible to cause damage to a vulnerable element.

ii) Vulnerable elements (V) are individuals (consumers, road users...), goods (houses...), or components of the environment likely to suffer damage in certain circumstances, because of exposure to a hazard.

iii) Damage (D) means harm to a physical component (crack, spoil) or a person (physical, or psychological injury), caused by a third party. The division of risk into these three aspects (H/V/D) will provide a reading grid to compare risk models in the following sections.

Risk models (M2) can be classified according to the vulnerable elements impacted. For instance :

1. the presence of a leak or work (repair or replacement of pipe) on the network can impact consumers who have less or no water in the tap.

2. the presence of a leak or work on the network can impact road users (car, bus, tram etc. ). This induces road cuts and traffic congestion.

3. huge leaks can flood housing or industrial areas.

4. ferruginous red water or black water (rich in manganese) can reach the consumer's tap .

5. residents can be bothered by noise or dust during work, etc. 


\begin{tabular}{|c|c|c|}
\hline Physical factors & Environment factors & Operational factors \\
\hline Pipe age and material & Pipe bedding & $\begin{array}{l}\text { Internal water pressure, } \\
\text { transient pressure }\end{array}$ \\
\hline Pipe wall thickness & Trench backfill & Leakage \\
\hline Pipe vintage & Soil type & Water quality \\
\hline Pipe diameter & Goundwater & Flow velocity \\
\hline Type of joints & Climate & Backflow potential \\
\hline Thrust restraint & Pipe location & $\begin{array}{l}\text { Operation and maintenance } \\
\text { practices }\end{array}$ \\
\hline Pipe lining and coating & Disturbances & \\
\hline Dissimilar metals & Stray elecrical currents & \\
\hline Pipe installation & Seismic activity & \\
\hline Pipe manufacture & & \\
\hline
\end{tabular}

\section{Figure 2. Factors Contributing to Water System Deterioration (Al-Barqawi and Zayed, 2006).}

For example, some models are able to predict the first risk of having insufficient water, i.e. interrupting water supply to consumers, hospitals, businesses, fire hydrants... (cf. PARMS, CARE-W, Criticite, Aware-P...). The indicators and models used by these different applications vary in terms of complexity. Some programs use hydraulic models ( $c f$. CARE-W-RelNET), while others do not ( $c f$. PARMS). However, risk is in all cases are constructed in the same way: a) Probability (P) of failure $\otimes$ b) intensity (I) of the failure $\otimes c$ ) at least one consumer-related characteristic (vulnerable element) : quantity (Q), sensitivity (S) or value (\$) [see Eq. (1)].

$$
R_{D}=\left(P_{H} \times I_{H}\right) \times\left(Q_{V} \times S_{V} \times \$_{V}\right)
$$

where :

- probability measures the likelihood of occurrence, expressed by a number between 0 and 1, 0 indicating an impossibility and 1 an absolute certainty (ISO 73, 2009).

- Intensity reflects the importance of a phenomenon (Dauphine, A., 2001).

- Quantity is a weight, volume, number that determines a material portion, a collection of things (Jeuge-Maynart, I et al., 2011).

- Sensitivity is a factor of proportionality between the effects that vulnerable elements face and the damage suffered (Circulaire IC, 2005).

- Value is a generic concept, describing what worth an object that can be traded, sold, and, in particular, its price. Importance attached in price subjectively to 
something. (Jeuge-Maynart, I et al., 2011). Value can be used for non-tangible components (like human life or environment), but there is here a matter for discussion.

All of these risk indicators require the probability of future failure to be estimated. However, this calculation is made difficult by a number of different factors. Therefore powerful deterioration models are needed to assess this probability.

\section{DETERIORATION MODELS}

\section{Preliminary}

Deterioration models allow the estimation of future probable failure rate. A distinction can be made between deterministic models and statistico-probabilistic models.

\begin{tabular}{l|l|l|l|}
\multicolumn{2}{|c|}{ Deterministic models } & \multicolumn{1}{c|}{ Statistico-probabilistic models } \\
\hline \multicolumn{1}{|c|}{ Name } & \multicolumn{1}{|c|}{ Origin } & \multicolumn{1}{c|}{ Name } & \multicolumn{1}{c|}{ Origin } \\
\hline Kanew-linear & (Kropp, 2013) & Weibull & (Eisenbeis, 1994) \\
Kanew-exponential & (Kropp, 2013) & Poisson & (Malandain, 1999) \\
Shamir et al. 1979 & (Shamir et al. 1979) & NHPP & (Rostum, 2000) \\
Clark et al. 1982 & (Clark et al. 1982) & LEYP & (Le Gat, 2009) \\
Vision & (UKWIR, 2009) & & \\
\hline
\end{tabular}

Figure 3. Origins of some deterministic and statistico-probabilistic models

\section{Deterministic models}

Determinism is a school of thought which advocates that the sequence of events and phenomena is due to the principle of causality. Links can often be described by physical or mathematical equations whose parameters can be determined from actual data or expert opinion.

These models take into account different factors in order to predict future failure rate but all include at least the age of the pipes (see figure 4).

All these models can be used over the long term and generally either at the scale of the network or at the scale of a group of pipes (physical district metered area or cohort of same material).

Deterministic models are quite simple but doesn't fit very well. For example, the model (Clark et al., 1982) which seems to be the most complex reflects reality with a $R^{2}=0.47$ ( for a large water utility on short term) ${ }^{1}$ (Clark et al., 1982). However their simplicity makes them easy to be introduced in long-term models that contain other useful options for the manager (calculation of renewal and budget need) (see Kanew software).

\footnotetext{
${ }^{1}$ the $R^{2}$ or coefficient of determination indicates how well data points fit a line or curve. It varies from 0 (no fit) and 1 (100\% adjustment ).
} 


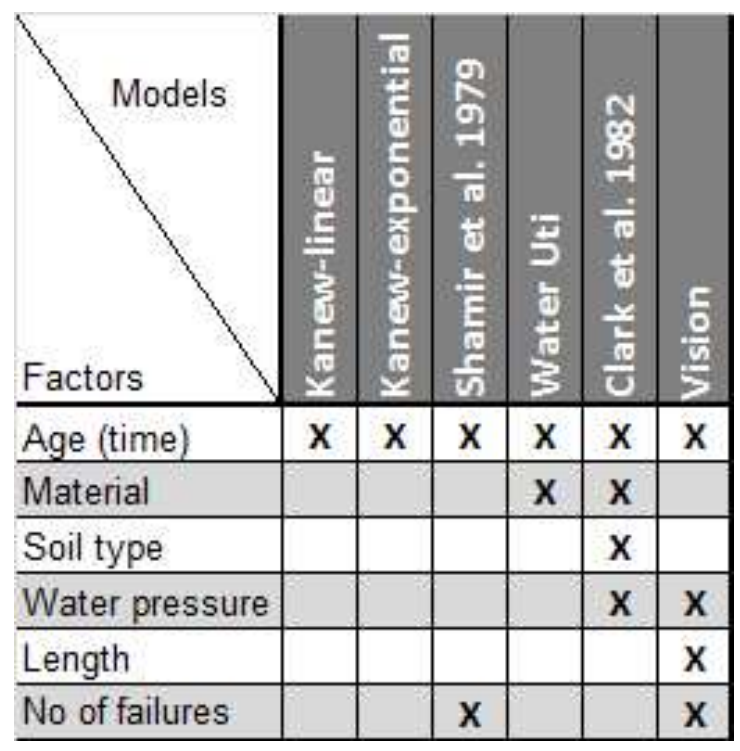

Figure 4. Factors taken into account for failure prediction in different deterministic models

\section{Statistico-probabilistic models}

In this section we will present exclusively statistico-probabilistic models. These models rely on the theory of probabilities, ie the mathematical study of phenomena characterized by randomness (evolution in the number of failures of a pipe / or monitoring the age at the end of service life of a group of pipes). A group of pipes with the same factor (see figure 2) do not all have the same failure rate. There is a residual part that can not be explained by these factors. The statistico-probabilistic models formalize this residual part by a probability distribution. To estimate the parameters of these models, we first made statistics on actual past data. The method of maximum likelihood (or log-likelihood) is the most commonly used to estimate the parameters of these models.

The input data of these models are : the characteristics of the pipes, their environment (traffic, climate, soil etc.) (see figure 2) and their failures (failure time, description, ID pipe, etc . )

Statistico-probabilistic models have the ability to greatly improve the prediction quality of failure rate when compared with deterministic models. All this models came from a theory developed by (Cox, 1972). Statistico probabilistic software for failure prediction usually contain a single model. For instance CARE-W-PHM contains the Weibull model (see figure 5). However some software contain several option for modelling the statistical distribution of the random variable that the user can use according to the amount of input data available. Thus, in the MOSARE software if the water utility has not a lot of data, the method implemented is a multi-criteria analysis, if the water utility has more data, the Poisson model is applied and if there is much 
data it will be the Weibull model.

\begin{tabular}{l|c|c|c|c|} 
Software/ Models & Weibul & Poisson & NHPP & LEYP \\
\hline CARE-W-PHM & $\mathrm{X}$ & & & \\
CARE-W-Poisson & & $\mathrm{X}$ & & \\
CARE-W-NHPP & & & $\mathrm{X}$ & \\
Casses & & & & $\mathrm{X}$ \\
Aware-P & & & $\mathrm{X}$ & $\mathrm{X}$ \\
SIROCO & & & & $\mathrm{X}$ \\
PARMS & $\mathrm{X}$ & $\mathrm{X}$ & & $\mathrm{X}$ \\
MOSARE & & & & $\mathrm{X}$ \\
PREVOIR & & $\mathrm{X}$ & & \\
\hline I-WARP & & &
\end{tabular}

Figure 5. Model implemented by the software

\begin{tabular}{l|c|c|}
\multicolumn{1}{|c|}{ Models } & $\begin{array}{c}\text { Prediction of } \\
\text { failure rate }\end{array}$ & $\begin{array}{c}\text { Hierarchy of pipes by } \\
\text { probable failure rate }\end{array}$ \\
\hline Weibull & - & + \\
\hline Poisson & + & - \\
\hline NHPP & + & - \\
\hline LEYP & + & + \\
\hline
\end{tabular}

Figure 6. Advantages and disadvantages of different models

The Weibull model produced a good ranking of pipes by the future probable rate (relative value) of failure compared to reality. Poisson models and NHPP (Non Homogeneous Poisson Process) have a good prediction of the (absolute value) failure rates compared to reality. LEYP (Linear Extended Yule Process) model is a model which synthesizes these two advantages (see figure 6) (Eisenbeis et al., 2002a; Eisenbeis et al., 2002b; Eisenbeis et al., 2003; Eisenbeis et al., 2004; Le Gat, 2009; Martins, 2011).

\section{RISK MODELS}

\section{Preliminary}

We presented above five different risks classified regarding the vulnerable element that can be impacted. We will now focus on models able to assess the risk of having insufficient water (see figure 7).

\section{Model concept}

In this risk calculation : 


\begin{tabular}{|l|l|l|}
\multicolumn{1}{c|}{ Models } & \multicolumn{1}{c|}{ Origin } & \multicolumn{1}{c|}{ Country } \\
\hline CARE-W-ARP & (Le Gauffre et al., 2002) & France \\
\hline CARE-W-ReINET & (Viscor, 1997) & Czech Republic \\
\hline Criticité & (Bremond, 2005) & France \\
PARMS & (Burn et al. 2003) & Australia \\
\hline Aware-P & (Vitorino et al. 2012) & Norway \& Portugal \\
\hline
\end{tabular}

Figure 7. Origin of risk models

- vulnerable elements considered are the consumers of water

- the hazard considered is a failure inducing a decrease in water flow or in the worst case interrupting water supply to consumers

- the severity of the damage potentially caused depends then on two dimensions of hazard: its probability of occurrence and its intensity (time to repair the failure); and on three dimensions of vulnerable elements affected by hazard: their quantity, their sensitivity, and their value.

\section{Discussion}

All indicators presented in Figure 8 do not necessarily take into account all the aspects presented above and in equation 1 (see empty cells in Figure 8).

For example, $\mathrm{HCl}$ characterizes the severity of the damage when the probability of failure occurs is $100 \%$. HCI is the only indicator in which there is a real hydraulic calculation.

$I E$ however is not really an indicator characterizing the potential damage because this indicator does not account for any parameter related to the consumers.

$C$ is the most comprehensive indicator of those presented above since all dimensions are covered. However for reasons of simplicity the same coefficient takes into account both sensitivity and value dimension.

Finally only $C_{\text {customer }}$ contains a coefficient which takes into account the monetized value of users.

\begin{tabular}{c|c|c|c|c|c|c|}
\multirow{2}{*}{ Risk } & Risk & \multicolumn{2}{c|}{ Hazard (failure) } & \multicolumn{3}{c|}{ Vulnerable elements (consumers) } \\
\cline { 4 - 7 } Software & Indicator & Probability & Intensity & Quantity & Sensitivity & Value \\
\hline CARE-W-ARP & $\mathrm{PCWII}$ & $\mathrm{X}$ & $\mathrm{X}$ & & $\mathrm{X}$ & \\
\hline CARE-W-ARP & $\mathrm{PWI}$ & $\mathrm{X}$ & $\mathrm{X}$ & $\mathrm{X}$ & & \\
\hline CARE-W-ReINET & $\mathrm{HCI}$ & $\mathrm{X}$ & & $\mathrm{X}$ & & \\
\hline Criticité & $\mathrm{C}$ & $\mathrm{X}$ & $\mathrm{X}$ & $\mathrm{X}$ & $\mathrm{X}$ & $\mathrm{X}$ \\
\hline Water Uti & $\mathrm{IE}$ & $\mathrm{X}$ & $\mathrm{X}$ & & & \\
\hline PARMS & $\mathrm{C}_{\text {customer }}$ & $\mathrm{X}$ & $\mathrm{X}$ & $\mathrm{X}$ & & $\mathrm{X}$ \\
\hline Aware-P & UDY & $\mathrm{X}$ & $\mathrm{X}$ & $\mathrm{X}$ & & \\
\hline
\end{tabular}

Figure 8. Factors taken into account in risk calculation in different models of software 


\section{SUMMARY AND PERSPECTIVES}

There is a high variability of the pipe service lives. While some pipes installed 150 years ago are still in full working order, some younger pipes may have a high failure rate and need to be replaced soon. The broad range of explanatory factors calls for the use of a powerful prediction models. In the software applications studied, models used can be divided into two categories: i) On the one hand, there are models able to make long term calculation ( $>50$ years). These models consider the network as split into broad groups of pipes, each group being characterized by a given lifetime, either in a deterministic ( $c f$. NESSIE) or probabilistic ( $c f$. the Herz function (Herz, 2002) in KANEW, PiReM...) way. ii) On the other hand there are models able to make short term $(<5$ years) calculations. These tools estimate future failure rate of each pipe segment through statistical/probabilistic models like Weibull (followed by Monte Carlo simulation), Poisson regression ( $c f$. I-WARP), Non Homogeneous Poisson Process ( $c f$. CARE-W-NHPP) or Linear Extended Yule Process( $c f$. PARMS-priority, Casses, Aware-P...).

All these models have their own set of advantages and disadvantages. The advantage of the first category is that they are able to assess the consequences in terms of service quality (performance) and can include long term financial calculations such as the whole life cost or cost benefit analysis, whereas the advantage of the second is that they hierarchize the network segments according to their risk level, in order to optimally allocate the annual renewal budget. The disadvantage of the first category is that residual lifetimes are based on expert knowledge, not on real water utilities' past data, whereas the disadvantage of the second is that future failure probability is only an extrapolation of what happened in the past.

A pivotal research question is then raised: is it possible to build long term survival functions in compliance with risk-based short term decision models?

\section{REFERENCES}

Al-Barqawi, H., and Zayed, T. (2006). Condition Rating Model for Underground Infrastructure Sustainable Water Mains. J. of Performance of Constructed Facilities, 20(2), 126-135.

Ana, E. V. and Bauwens, W. (2010). Modeling the structural deterioration of urban drainage pipes: the state-of-the-art in statistical methods. Urban Water J., 7, 47-59.

Bremond, B.; Laplaud, C.; Huchin, B.; De Massiac, J. C. and Renaud, E. (2005). Systme integre daide au renouvellement optimise des conduites adapte aux petites et moyennes collectivites : SIROCO. CEMAGREF, G2C Environnement, 189.

Burn, S.; Tucker, S.; Rahilly, M.; Davis, P.; Jarrett, R. and Po, M. (2003) Asset 
planning for water reticulation systems the PARMS model. Water Science and Technology: Water Supply, 3, 55-62.

Circulaire IC (2005). Circulaire relative aux installations classees du 7 octobre 2005. 18.

Clark, R. M.; Stafford, C. L. and Goodrich, J. A. (1982). Water distribution systems: a spatial and cost evaluation. $J$. of the water ressources, planning and management, 108, 243-256.

Cox, D. R. (1972) Regression Models and Life-Tables. J. of the Royal Statistical Society. 34, 187-220.

Dauphine, A. (2001). Risques et catastrophes. Observer, spatialiser, comprendre, gerer. Armand Colin.

Eisenbeis, P. (1994) Modelisation statistique de la prevision des defaillances sur les conduites d'eau potable Universite Louis Pasteur Strasbourg, 190.

Eisenbeis, P.; Le Gat, Y.; Laffrechine, K.; Le Gauffre, P.; Konig, A.; Rostum, J.; Tuhovcak, L. and Valkovic. P. (2002a). D3, CARE-W : WP2 Description and validation of technical tools, Report 2.1 models description Cemagref Bordeaux, INSA Lyon, SINTEF, NTNU, Brno University of Technology, 120.

Eisenbeis, P.; Le Gat, Y. and Poulton, M. (2002b). Failure forecast and hydraulic reliability models for rehabilitation decision aid. International Conference for Computer aided rehabilitation of water networks (CARE-W), in Dresden Germany, November 1st., 97-106.

Eisenbeis, P.; Laffrechine, K.; Le Gauffre, P.; Le Gat, Y.; Rostum, J.; Tuhovcak, L. and Valkovic. P. (2003). D4, CARE-W : WP2 Description and validation of technical tools, Report 2.2 Tests and validation of technical tools. Cemagref Bordeaux, INSA Lyon, NTNU, Brno University of Technology, 2003, 58.

Herz, R. (2002). Developing rehab strategies for drinking water networks, Dresden University of Technology, Germany Proceedings of the 9 DBMC International Conference on Durability of Building Materials and Components, 11.

ISO-73. (2009). International Organization for Standardization, Norme, ISO guide. Management du risque, Vocabulaire. 25.

Jeuge-Maynart, I.; Girarc-Marinier, C. and Florent, J. (2011). Le petit larousse illustre 2011.

Kropp, I. (2013). Kanew software, version 4, manual. 2013, 76.

Le Gauffre, P.; Laffrechine, K. and Rolf, B. (2002). D6, CARE-W : WP3 Decision Support for Annual Rehabilitation Programmes, Report 3.1 Criteria for the prioritisation of rehabilitation projects. INSA Lyon.

Le Gat, Y.(2009) Une extension du processus de Yule pour la modelisation stochastique des evenements recurrents. Application aux defaillances de canalisations d'eau sous pression. Institut des Sciences et Industries du Vivant et de lEnvironnement (AgroParisTech), 121.

Liu, Z., Kleiner, Y., Rajani, B., Wang, L. and Condit, W. (2012). Condition assessment technologies for water transmission and distribution systems. United States Environmental Protection Agency (EPA), 108. 
Malandain, J. (1999) Modelisation de l'etat de sante des reseaux de distribution d'eau pour l'organisation de la maintenance : etude du patrimoine de l'agglomeration de Lyon. Institut National des Sciences Apliquees (INSA) de Lyon, 206.

Martins, A. (2011). Stochastic models for prediction of pipe failures in water supply systems. Instituto Superior Tecnico, Universidade tecnica de Lisboa, 85.

Renaud, E.; Le Gat, Y. and Poulton, M.(2012). Using a break prediction model for drinking water networks asset management: From research to practice. Water Science and Technology: Water Supply, 12.5, 674-682.

Rostum, J. (2000). Statistical Modelling of Pipe Failures in Water Networks Norwegian University of Science and Technology, Department of Hydraulic and Environmental Engineering, Trondheim, Norway, 132.

Shamir, U. and Howard., C. (1979). An analytic approach to scheduling pipe replacement. Journal of American Water Works Association, 71, 248-258.

Taillandier, F.(2009). La notion de risque comme clef du pilotage dun parc patrimonial immobilier Universite de Savoie, specialite : genie civil, 331.

UKWIR (2009). Factors Affecting the Natural Rate of Rise of Leakage, 09/WM/08/40 UKWIR (United Kingdom Water Industry Research).

Viscor, P. (1997). Spolehlivost vodovonich siti University of Technology, Brno, Czech Republic

Vitorino, D.; Coelho, S. T.; Alegre, H.; Martins, A.; Leitao, J. P. and Silva, M. S.(2012). Aware-P software documentation. 38. 